\title{
The limiting factors of land suitability for sandalwood (Santalum album) in Sumba Island, Indonesia
}

\author{
HERY KURNIAWAN ${ }^{1, \bullet}$, DANI PAMUNGKAS ${ }^{2, \bullet \bullet}$ \\ ${ }^{1}$ Forest Plants Fiber Technology Research and Development Institute of Kuok. Jl. Raya Bangkinang-Kuok Km. 9, Kampar 28401, Riau, Indonesia. \\ Tel.: +62-811-7500764, Fax.: +62-762-21370, `email: herykurniawan2012@gmail.com \\ ${ }^{2}$ Forestry and Environment Research and Development Institute of Kupang. Jl. Alfons Nisnoni No. 7b, Airnona, Kupang 85115, East Nusa Tenggara, \\ Indonesia. Tel.: +62-380-823357, Fax.: +62-380-831068. ^v email: dani.mungkas@ gmail.com
}

Manuscript received: 22 January 2020. Revision accepted: 28 June 2020.

\begin{abstract}
Kurniawan H, Pamungkas D. 2020. The limiting factors of land suitability for sandalwood (Santalum album) in Sumba Island, Indonesia. Biodiversitas 21: 3364-3372. The land suitability assessment for sandalwood is very important for the successful cultivation and development of sandalwood (Santalum album Linn.) in Sumba Island, East Nusa Tenggara Province, Indonesia. The map of land suitability classification for sandalwood is currently available. The land suitability assessment is determined based on designated indicators and predictors. It is important to identify the most influential measures in a particular area to determine the suitable treatment to be applied to the sandalwood plant, as well as to recognize the land suitability evaluation swiftly and efficiently. This study was aimed to determine the variables of indicators or verifiers that have the strongest relationship with the land suitability class for sandalwood. Regression method was used to develop the relationship model and to determine the level of the relationship through the coefficient of determination. The result shows that $\mathrm{P}_{2} \mathrm{O}_{5}$ content was the most influential factor to determine the land suitability class for sandalwood in Sumba Island.
\end{abstract}

Keywords: Indicators, land suitability, regression, sandalwood

\section{INTRODUCTION}

Sandalwood is an endemic plant in East Nusa Tenggara (ENT), Indonesia that is widely known for its distinguished wood fragrance which utilized for various products e.g. raw materials of incense, cosmetics, handicrafts, etc. Indian women have long used herbs such as Sandalwood and Turmeric for skincare (Gediya et al. 2011). The oil has potential uses in cosmetic and external pharmaceutical applications (Hettiarachchi et al. 2010). Sandalwood from ENT is recognized as East Indian sandalwood in the international market (Burdock and Carabin 2008). In the context of local culture of ENT, sandalwood has become significant part of the local wisdom of the community, had even become the icon of ENT that is well recognized globally. In East Nusa Tenggara, sandalwood had had contribution to local revenue in terms of regional income at about IDR. 2.5 billion/year or approximately 40 percent of provincial income during 1986-1992 (Seran et al. 2018; (Septiani and Setyawati 2012). Sandalwood has unique properties and although the current supply is still limited yet it has high demand prospects in the future (Peden et al. 2017).

The management of sandalwood changes over time, which certainly affects the sustainability of sandalwood population. Sandalwood, which is locally known as Cendana, is economically valuable for the government, market/ entrepreneur, and community in East Nusa Tenggara. The ups and downs of the market, wood supply, and regeneration sustainability of this plant in nature highly depend on the role of those three economic actors (Rohadi et al. 2012). Currently, the market of cendana in East Nusa Tenggara declined due to various factors. Efforts to restore the glorious time of cendana in East Nusa Tenggara still continue through every conceivable means, i.e. management policy, management systems, and immediate actions involving related stakeholders, i.e. local government, private companies, non-governmental organizations and the community in general. Integrated, transparent, efficient, and synergistic measures must be developed and implemented to achieve the utmost benefit for the prosperity and welfare of the society. One important measure is the availability of maps on land suitability classification for this valuable sandalwood. Currently, maps of land suitability class for sandalwood on four major islands in East Nusa Tenggara, i.e. Timor, Sumba, Alor, and Flores Island are already available. The local government in Sumba needs to develop sandalwood plantation due to its potential economics and customer value.

The improper sandalwood planting strategy and planning resulted in the failure of the planting. Sandalwood is a typical plant that has the character and suitability of a typical place to grow as well. The concept of land suitability for sandalwood is very necessary to increase the success of planting, because not all places in East Nusa Tenggara will be truly suitable for sandalwood cultivation. Akpoti et al. (2019), stated that Agricultural Land Suitability Analysis (ALSA) is a worldwide land-use planning approach. The factors used in analysis could be categorized in climatic conditions, nutrients and favorable soils, water availability in the root zone, and socio- 
economic and technical requirements. In this study, we did not use all of these categories, due to some categories had been included naturally and customary. Climatically, all places of Sumba Island are suitable for sandalwood growth. And socio-economically, sandalwood has long been recognized as a traditional plant that has high economic value. So, in this study, practically only used nutrients and favorable soils for analysis.

The map of land suitability assessment designates the land suitability assessment for sandalwood based on certain criteria, indicators, and predictors simultaneously. However, the most influential indicator or predictor has not definitely identified yet. This information will be useful for a quick method to determine land suitability assessment for sandalwood. Therefore, this recent study addressed that issue and sought to provide more detailed information on the most influential predictor of the land suitability classification for sandalwood. Then the planning of plantation could be more accurate and efficient.

\section{MATERIALS AND METHODS}

\section{Materials and study area}

In this study, soil samples were taken from various soil types and land covers in Sumba Island in 2012. Tools e.g. GPS, ring samples, iron diggers, hoes, masking tape, and markers were assigned in this study. Several maps were used to support the work, i.e. the basic map of Sumba region, map of land cover, and map of land suitability classification for sandalwood. Sumba is one of the four big islands in East Nusa Tenggara Province, Indonesia. Geographically located at $9^{\circ} 16^{\prime}-10^{\circ} 20^{\prime} \mathrm{S}$ latitude and $118^{\circ}$ $55^{\prime}-120^{\circ} 52^{\prime}$ E longitude (Figure 1).

The map of land suitability assessment includes various indicators and predictors, e.g. soil N, P, K, Bo, Ca, texture, etc. The existing indicators and predictors of the area were then weighted based on the importance of these elements referring to reputable previous studies. The resulted scores were then used to determine the class of land suitability in absolute terms. Thus, the land unit can be classified into the suitability classification of 1, 2, 3, and 4 accordingly (Kurniawan and Sumardi 2013).

\section{Data analysis}

The land suitability assessment only used nutrient and soil factors based on the ALSA and did not include climate, socio-economic, and water availability because the last three factors naturally available. Land suitability was determined in procedure that is commonly used by matching the quality or characteristics of the land unitsample with the ideal land requirement for the desired growth of sandalwood. In this matching system, a minimum law was applied, in which the land suitability class would be determined by the toughest constraint factor (Mega et al. 2010).
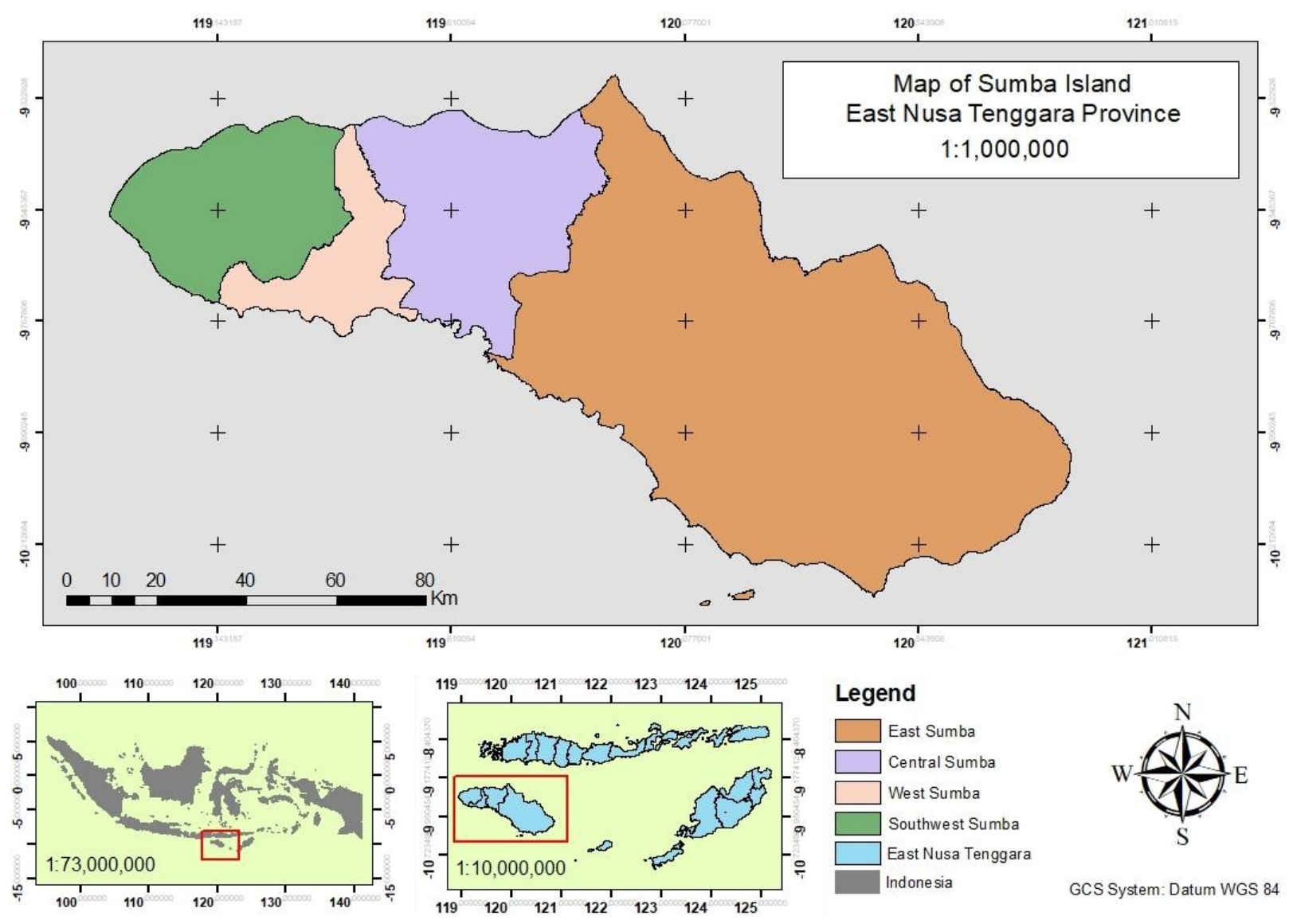

GCS System: Datum WGS 84

Figure 1. Map of Sumba Island, East Nusa Tenggara Province, Indonesia 
Regression analysis highly depends on the results of correlation analysis. Correlation test will linearly determine the relationship within the land characteristics thus significant correlation between particular land characteristics could be identified. Furthermore, a particular land characteristic may closely describe other particular characteristics thus could be used as a substitution for each other (Liyanda et al. 2012). Regression analysis was applied to primary data obtained from soil analysis at soil laboratory of Agriculture Faculty of Nusa Cendana University in East Nusa Tenggara, also on data of land suitability for sandalwood of the previous researches. The verifiers were designated based on the characteristic of Santalum album Linn. in taking the nutrition for their growth. The available primary data were sorted based on the designated verifiers, then was subsequently analyzed by regression to identify the verifier with the strongest relationship with the land suitability classification. The coefficient of determination $\left(R^{2}\right)$, the significance value, and the standard error were parameters used to determine the selection of the most reliable equation model (Mascaro et al. 2011; Jara et al. 2015; Diedhiou et al. 2017). Each indicator does not actually affect land suitability classes separately. Multivariate analysis was conducted to determine the effect of all indicators on land suitability classes. Discriminant analysis is used because the dependent variable is non-metric data.

\section{RESULTS AND DISCUSSION}

The number of populations of Santalum album in the natural habitat has experienced substantial decrease due to extensive exploitation for commercial purposes (Teixeira da Silva et al. 2016). The conservation status of S. album alone has been on a level of vulnerability as listed by International Union for Conservation of Nature and Natural Resources (IUCN 2015) after the assessment of conservation status held in Viet Nam in 1998. Maps of land suitability related to sandalwood in East Nusa Tenggara, including in Sumba Island, is currently available so as to support the efforts on conservation and development of sandalwood.

The distribution of $S$. album is mainly covering Australia, Indonesia, and India (Teixeira da Silva et al. 2016). As Timor, Sumba Island and the East Nusa Tenggara region in general, are known as the center of natural distribution of sandalwood in the world thus the ecological conditions of those areas are already proven as very suitable for the growth of sandalwood. The natural habitat of sandalwood in East Nusa Tenggara is sporadically distributed in 9 districts, i.e. Kupang, Timor Tengah Selatan (TTS), Timor Tengah Utara (TTU), Belu, West Sumba, East Sumba, Manggarai, Alor, and Solor.

\section{Nutrients fact of sandalwood}

The growth of sandalwood is closely affected by its growth environment, especially the soil conditions and host plant because of its hemiparasitic nature (Liu et al. 2009; Ouyang 2015; Teixeira da Silva et al. 2016). According to the growing habitat of sandalwood, sandalwood can be found in latosols with sediment rock and volcanic, in some areas, sandalwood can also be found in a site with association of a black grumusols and red Mediterranean, or latosols with limestone rocks (Ratnaningrum et al. 2016). Sandalwood requires fertile soil with good drainage to exhibit optimum growth. The preferable soil type for sandalwood is litosol (red Mediterranean) with neutral to slightly alkaline soil $\mathrm{pH}$, moderate $\mathrm{N}$ content and moderate to high $\mathrm{P}_{2} \mathrm{O}_{5}$ content, and high $\mathrm{K} / \mathrm{Ca}$ ratio in pre-parasitic seedling (Struthers et al. 1986; Barrett and Fox 1997; Brand et al. 2013). In East Nusa Tenggara, according to study of Seran et al. (2018), sandalwood can be cultivated in a field-level with various elevations of between 383.8 and $1038 \mathrm{~m}$ above sea level (m asl.).

The presence of a host plant for sandalwood has been proven to be essential in the root association through haustoria formation for supplying water and other available nutrients to improve morphological growth (Deepa and Yusuf 2016). Sandalwood develops strategy by modifying the roots to form haustorium when in physical contact with the roots of the host plants. The formed haustorium would connect sandalwood to the host plant, in terms of anatomically, morphologically, and physiologically. That connection thus would allow the flow of water and nutrients from the host plant to the parasite plant (Luo and Guo 2010; da Silva et al. 2016). Within a year since Sandalwood was grown with the host plants, it would manage to form the haustorium between their roots ( $\mathrm{Lu}$ et al. 2014). Root haustorium of sandalwood with krokot (Alternanthera sp.) was found to support the absorption of water and nutrients. Haustoria formed under root association between sandalwood and host plant showed varied growth performance of sandalwood. Sandalwood tends to grow better with leguminous plants compared to non-leguminous as intermediate host plants, such as Sesbania formosa compared to Eucalyptus camaldulensis and Sesbania grandiflora to Casuarina junghuhniana (Radomiljac et al. 1999; Gomes and Adnyana 2017). Meanwhile, at pot host level, sandalwood grows better with a species of Althenantera nana compared to S. formosa (Radomiljac 1998).

Sandalwood that grew with host plants showed a higher $\mathrm{N}, \mathrm{P}$, and $\mathrm{K}$ content in their leaves (Rocha et al. 2014). The presence of host plants in sandalwood cultivation is advisory because of their role as sources of $\mathrm{K}, \mathrm{P}, \mathrm{Ca}$, and $\mathrm{Na}$, even N, and C (Lu et al. 2013; Teixeira da Silva et al. 2016). Brand et al. (2003) reported that the concentration of $\mathrm{N}, \mathrm{P}, \mathrm{K}, \mathrm{Ca}, \mathrm{Mg}$ in the leaves of Santalum spicatum were significantly different at the various given host. Furthermore, Barrett and Fox (1997) noted that the low K content in the K-free treatment was found to coincide with the reduced number of haustoria and root development.

Sandalwood leaves generally had the highest concentration of minerals, followed by roots and stems. Compared with well-fertilized plants, treatment without $\mathrm{N}$ resulted in lower Ca concentration, particularly in the stem; 
lower $\mathrm{Mg}$ concentration especially in roots; higher concentration of $\mathrm{P}$ and $\mathrm{Cl}$ in leaves; and higher $\mathrm{S}$ concentration in leaves but lower in roots. In the treatment without $\mathrm{K}$, the $\mathrm{Ca}$ and $\mathrm{Na}$ concentration were increased; $\mathrm{Ca}$ especially on roots and $\mathrm{Na}$ in other parts besides roots. In the treatment without $\mathrm{P}$, the concentration of $\mathrm{K}$ and $\mathrm{Ca}$ were lower especially in the leaves; $\mathrm{NO}_{3}$ was lower in leaves but higher in roots and stems. In the treatment without $\mathrm{S}$, the $\mathrm{N}$ concentration was higher mainly in roots and stems, and $\mathrm{Cl}$ concentration was higher in all parts. In plants with treatments without $\mathrm{Ca}$, the $\mathrm{P}$ and $\mathrm{K}$ were higher than those with fertilizer treatment using all the nutrients (Barrett and Fox 1997).

The K/Ca ratio in the leaves of seedlings of $S$. album and adult of $S$. spicatum is the same. This high ratio in $S$. spicatum suggested a tendency for nutrient uptake of $\mathrm{K}$ than $\mathrm{Ca}$ that originated from host plants, This is common for parasitic angiosperm plants (Struthers et al. 1986). The results showed that this ratio had already attained prior to the attachment to the host and presumably was the nature of sandalwood whether the attachment occurred or not (Barrett and Fox 1997).

In condition of lack of $\mathrm{N}, \mathrm{K}$, and $\mathrm{P}$, growth can continue up to about three months, but it could grow independently for much longer time despite lack of $\mathrm{Ca}$ or $\mathrm{S}$. Yet, S. spicatum in hydroponic experiments with free-Ca died within three weeks (Struthers et al. 1986).

The study by Barrett and Fox (1997) indicated that high concentration of $\mathrm{K}$ and $\mathrm{K} / \mathrm{Ca}$ ratio took place at preparasitic stage of $S$. album seedling. In the next stage, $S$. album would take N, P, and K from its host therefore at least for 3 months the required minerals could be met from the rooting system. Lack nutritional supply significantly affects plant morphology and mineral content. This condition allegedly limits the direct establishment of connection with host plants and hinders the process of parasitism thus their survival (Barrett and Fox 1997). The amount of SOM indicates the level of decomposition. High SOM concentration means high degree of decomposition that would provide available nutrients for sandalwood plants. Several researchers had shown that sandalwood shows a positive response to the addition of organic matter.

\section{Sandalwood land suitability in Sumba Island}

The land suitability classification for sandalwood was determined based on land suitability map in Sumba Island. The class I land is more suitable for S. album growth than the class II, the class II land is more suitable than the class III, and the class III land is more suitable than the class IV. The large of land suitability class I is $781.285,2$ ha, class II is $75.907,71$ ha and class IV is $4.995,41$ ha.

The results of land suitability analysis for class I are regency with the biggest area of land suitability class I were East Sumba $(473,573.1$ ha), Southwest Sumba (125,387 ha), Central Sumba (121,871 ha) and West Sumba $(60,454.14$ ha), respectively. The example of map of land suitability classification for sandalwood is presented in Figure 2.

Based on the selected indicators and verifiers as stated in the methodology, suitability class I corresponded to score of 30-40, class corresponded to score of 20-30, class III corresponded to score of 10-20, while class IV corresponded to the score of $0-10$. The score was calculated from the total score of the indicators from the weighting of each verifier.

\section{Regression analysis on verifiers and class of suitability}

Soil fertility properties, such as $\mathrm{N}, \mathrm{P}$, and $\mathrm{K}$ content, soil $\mathrm{pH}$, and organic matter content has been an important component to be considered in soil management. A study by Moyin-Jesu (2015) showed that addition of organic (rice bran, wood ash, and poultry manure) or inorganic (NPK 15-15-15) fertilization in media had significantly affected the growth of Brassica oleracea. Poultry manure, which was with highest $\mathrm{N}, \mathrm{P}, \mathrm{K}$, and organic matter, had increased better the soil fertility compared to other treatments. The high amounts of soil fertility subsequently affected better growth of the crops.

Regression analysis was done on each verifier to the suitability class. The verifiers were $\mathrm{N}, \mathrm{P}_{2} \mathrm{O}_{5}, \mathrm{~K} / \mathrm{Ca}$, and soil organic matters (SOM). The results of the analysis are presented as follows:

\section{Regression of $N$ vs. suitability class}

Nitrogen $(\mathrm{N})$ has been a foremost element on plant growth. In particular circumstances, such as drought, the sufficiently available $\mathrm{N}$ could increase the drought tolerance of a plant. Adequate $\mathrm{N}$ would also have paramount role in protein formation, which will affect the chlorophyll contents that subsequently affect the photosynthetic process (Abid et al. 2016).

$\mathrm{N}$ supply is required by plants which the green color of leaves has very strong positive relationships with leaf $\mathrm{N}$ concentration in the leaves, in which the greener the leaves indicate the higher the $\mathrm{N}$ contents in plant's leaves (Rorie et al. 2011). A study by Rorie et al. (2011) that used dark green color index (DGCI) showed that lower leaf $\mathrm{N}$ concentration would show lower DGCI.

The soil chemical properties analysis showed that nitrogen content in the soils of Sumba Island varies considerably and was ranging from $0.015 \%$ to $0.291 \%$ (Figure 3) which covered almost all of the categories: very low $(<0.1)$, low $(0.1-0.2)$, to moderate $(0.21-0.5)$. The Regression analysis revealed a weak relationship between $\mathrm{N}$ and suitability class of sandalwood $\left(\mathrm{R}^{2}=0.074\right)$ (Figure 2 ). This suggested that nitrogen is not a major limiting factor for sandalwood to grow well on Sumba Island. Nitrogen is fairly evenly spread in each suitability class. The $\mathrm{N}$ contents in the area most were only in moderate category that most likely was due to the dry-hot climatic condition and lack of vegetation cover. This moderate condition would result in the low number and activity of soil microbes. Bacterial and fungal symbiosis is an essential part of the ecosystem in all tropical forests, and most (indeed, probably all) plants will form at least one type of symbiosis and many will form more than one (James 2017). Nitrogen can be made available by plantassociated bacteria in the soil through nitrogen fixation, that is importantly needed by plant for growing (Mujahid 2015; James 2017; Mahmud et al. 2020). 


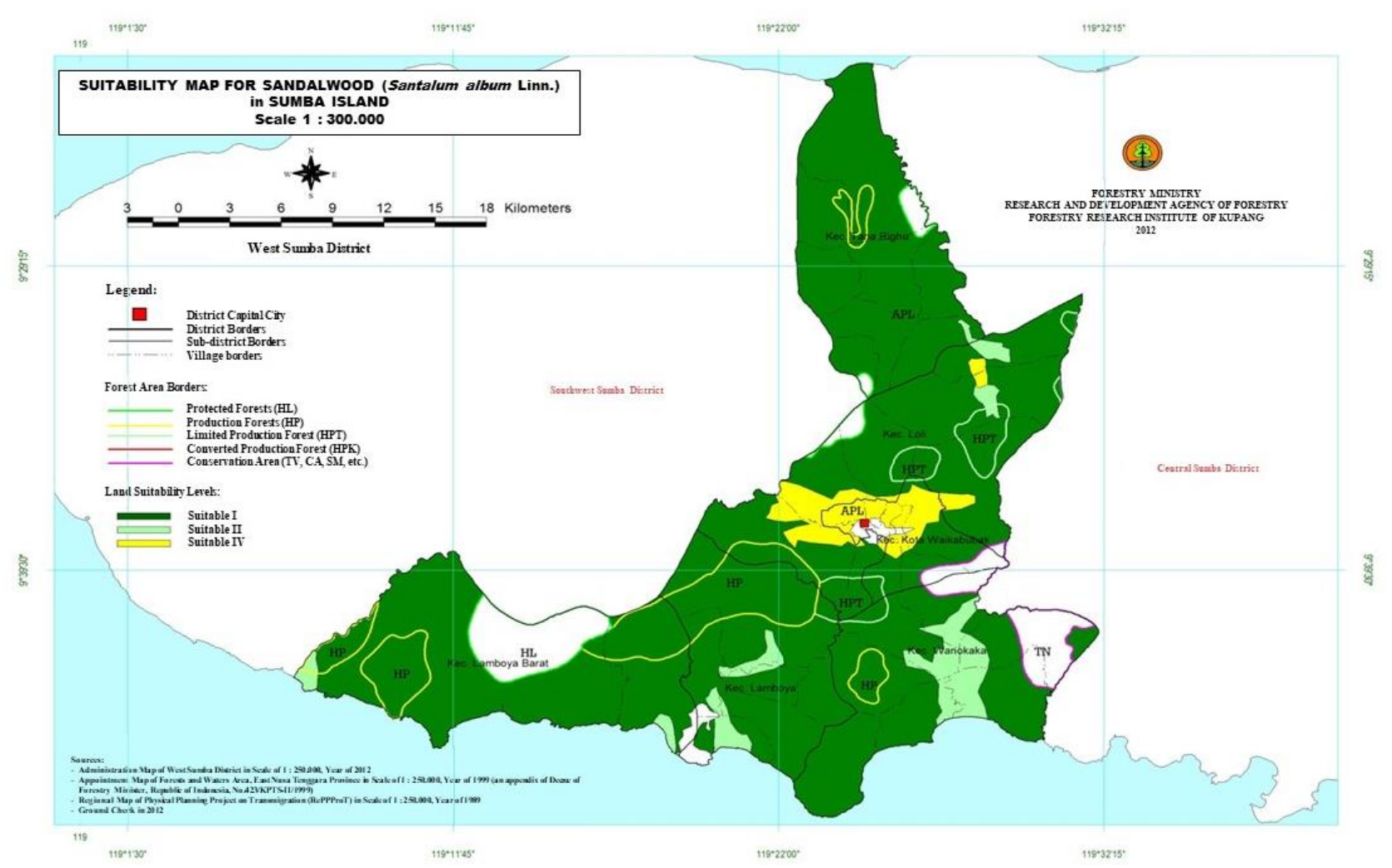

Figure 2. Example of map of land suitability class for sandalwood in West Sumba, East Nusa Tenggara Province, Indonesia

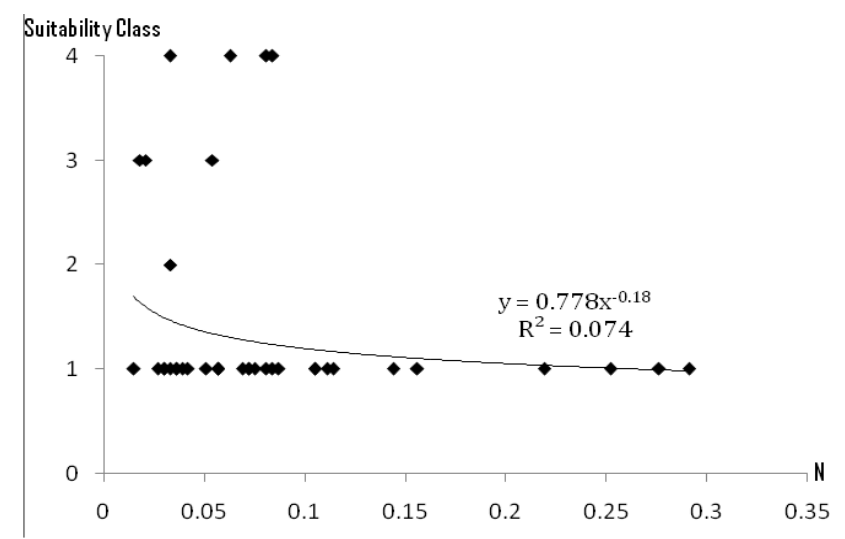

Figure 3. Regression of N vs. suitability class

Most regions in East Nusa Tenggara, including Sumba Island, have extreme agro-climatic conditions because of the location in an exceedingly distinct semi-arid ecosystem; this has limited the richness of the biodiversity in the area, especially flora (Hendrik et al. 2019). This condition is strongly suspected to be the major factor affecting the abundance of microbes in the soil that led to the low levels of available nitrogen in the soil.

\section{Regression of $\mathrm{P}_{2} \mathrm{O}_{5}$ vs. suitability class}

Phosphorus $(\mathrm{P})$ has an important key that is necessary in large amounts for growth metabolism and activity in cellular functions (Crous et al. 2015).

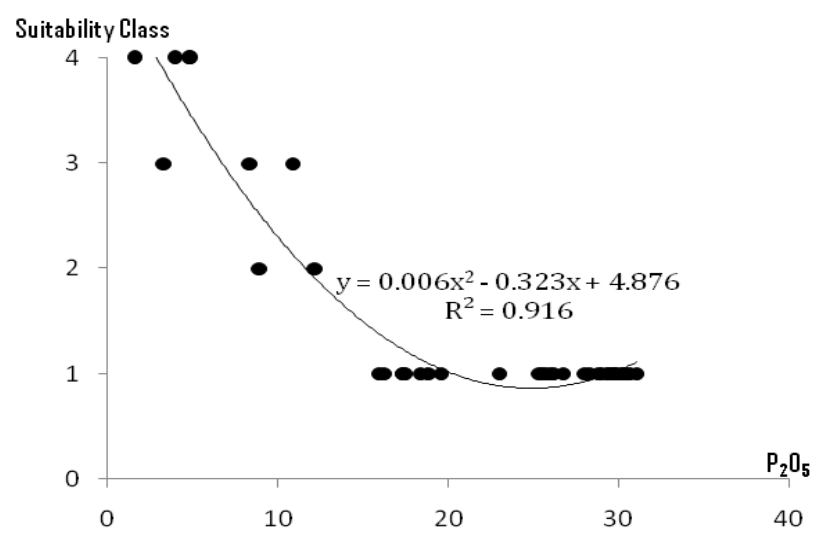

Figure 4. Regression of $\mathrm{P}_{2} \mathrm{O}_{5}$ vs. suitability class

Phosphorus in the form of $\mathrm{P}_{2} \mathrm{O}_{5}$ compound is profoundly important to plants for growth, which would facilitate to increase the availability of $\mathrm{P}$ in the soil (Prado 2010). Soil chemical analysis showed that the $\mathrm{P}_{2} \mathrm{O}_{5}$ contents in the soil of Sumba Island were varied from 1.58 ppm to 31,03 ppm (Figure 4). These values were fell within criteria of very low $(<5)$, low (5-10), moderate (11-15), high (16-20), and very high (> 20).

The regression analysis showed a very strong correlation between $\mathrm{P}_{2} \mathrm{O}_{5}$ with land suitability class for sandalwood in Sumba Island $\left(\mathrm{R}^{2}=0.916\right)$ (Figure 4). This 0.916 coefficient of determination inferred that approximately $91.6 \%$ of the land suitability variation can 
be explained by the regression equation, i.e. $y=0.006 x^{2}-$ $0.323 x+4.876$. The coefficient of variation $(\mathrm{CV})$ of the $\mathrm{P}_{2} \mathrm{O}_{5}$ values was 0.45 , which implied the rather lower distribution of $\mathrm{P}_{2} \mathrm{O}_{5}$ in each class. The $\mathrm{CV}$ was calculated by dividing standard deviation by the average of the calculated data or mean value (Kozak et al. 2013; Abdi 2010). Thus, CV is essentially a value that expresses the relative size of a data set to the average value of the data. Therefore this coefficient can be used to compare the extent of the dispersal of different data sets. The coefficient of variation is a measure of the dispersion that depends on the measured and relative value. Other research by Das et al. (2018) found that the higher the organic carbon and macro-nutrients ( $\mathrm{N}, \mathrm{P}$, and $\mathrm{K}$ ) content of the soil, the better is the growth (both height and girth) and survival of the sandalwood seedlings. This result was in accordance with the findings of Luo and Guo (2010), which reported that high $\mathrm{P}$ concentration could improve the metabolic ability of hemiparasite plants such as sandalwood.

The low CV indicated that the data was evenly dispersed close to the average value. $\mathrm{CV}$ defined the distribution of $\mathrm{P}_{2} \mathrm{O}_{5}$ data on each criterion (very low to very high) thus it may also significantly defined the variation of soil fertility. This condition should be very specific and may differ in different locations. Differences in the content of soil organic matter may result in the increased soil $\mathrm{P}$ content and $\mathrm{P}$ uptake by plants (Yu et al. 2013; Weil and Brady 2017), thus an increase in the availability of $P$ in the soil due to organic matter and P fertilizer could lead to the increased of P uptake by plants. According to Nur (2014), the dry condition of Timor Island with high content of exchangeable-calcium had presumably led to the low available-P content, even though the total soil phosphorus content was very high. The phenomenon of the low available-P was strongly suspected to also occur in Sumba Island as it has similar natural environment conditions to that of Timor Island. This further strengthens the conclusion that $\mathrm{P}$ is the major limiting factor for sandalwood in Sumba Island, perhaps even for all crop cultivation in the location.

\section{Regression of K/Ca vs. suitability class}

The value of $\mathrm{K} / \mathrm{Ca}$ in the soil analysis showed quite vary results. However, regression analysis revealed a low coefficient of determination that inferred the weak correlation of $\mathrm{K} / \mathrm{Ca}$ with the variation of land suitability class for sandalwood (Figure 5).

The K/Ca ratio is an important measure and one of the limiting factors for the growth of sandalwood. Element $\mathrm{K}$ was strongly suspected to be the key element for the growth of S. spicatum as the parasite Angiospermae plant has a tendency to absorb $\mathrm{K}$ rather than $\mathrm{Ca}$, so it generally has a high K/Ca ratio (Brand et al. 2013; Radomiljac et al. 1998).

$\mathrm{K}$ was also considered to play a key role in ensuring the direct flow of water from the host plant to the hemiparasite plant (Luo and Guo 2010). The water potential in sandalwood decreased with the removal of the host plants, indicated that the existence of $\mathrm{K}$ in sandalwood relied on the supply from the host plant (Rocha et al. 2014). This current results simply concluded that the $\mathrm{K} / \mathrm{Ca}$ in the soils of Sumba Island was considerably varied yet that variation showed less direct impact on the variation of land suitability classification for sandalwood. This means that the variation of $\mathrm{K} / \mathrm{Ca}$ on the island is still in the range that can be tolerated by sandalwood.

In this current study, the content of $\mathrm{K}$ in the soil of Sumba Island was ranging from medium to very high. This result was similar to that of Njurumana et al. (2008) who reported that $\mathrm{K}$ content in the land cover in the Kaliwu system in Sumba was generally high. Based on the finding, the soil available-K in Sumba Island relatively similar variation in general. Simply, $\mathrm{K}$ was considerably available thus was not a major limiting factor for sandalwood in Sumba Island.

\section{Regression of SOM vs. suitability class}

Soil organic matter (SOM) is one of the soil physical indicators that indicate soil fertility. Low SOM suggests low nutrient content in the soil which means low soil fertility. Conversely, high organic material is an indication of fertile soil. However, in terms of soil fertility, the rate of organic matters weathered or decomposed should also be put into consideration. Decomposition rate of organic matters may be affected by several factors, such as the types of organic matters. According to Nahrawi et al. (2011), leaves of crops between pineapple and sago have differed on decomposition rate and the remaining mass, that is pineapple (90\% mass loss) was easily decomposed compared to sago (30\% mass loss), consequently, affecting the $\mathrm{C} / \mathrm{N}$ ratio in which the sago had higher ratio than pineapple.

A study by Liu et al. (2009) at nursery level confirmed that media properties were critical to the growth of sandalwood, media with higher organic matter in combination with local soil would deliver better sandalwood growth at parameters of height, ground diameter, dried biomass, and seedling quality index; as these types of media would have lower soil bulk density with higher water-holding capacity that could promote root growth. The research by Verma et al. (2012) confirmed that application of soil amendment with organic matters (mix of teak and Leucaena leaf and FYM in equal amount) along with application of plant growth-promoting microbes provide better survival (90-100\%) and enhanced growth of sandal sapling in field. Similarly, the results of Taylor et al. (2005) concluded that combination of organic matter up to $60 \%$, in the media of soil or sand gave the best growth in seedlings of sandalwood. Meanwhile, according to Sarwar et al. (2008) elucidated the soil properties of physic and chemistry would be enhanced by the availability of organic matters that are playing an important role. Dryland such as Sumba Island, generally has thin layer of soil with low organic matter. 


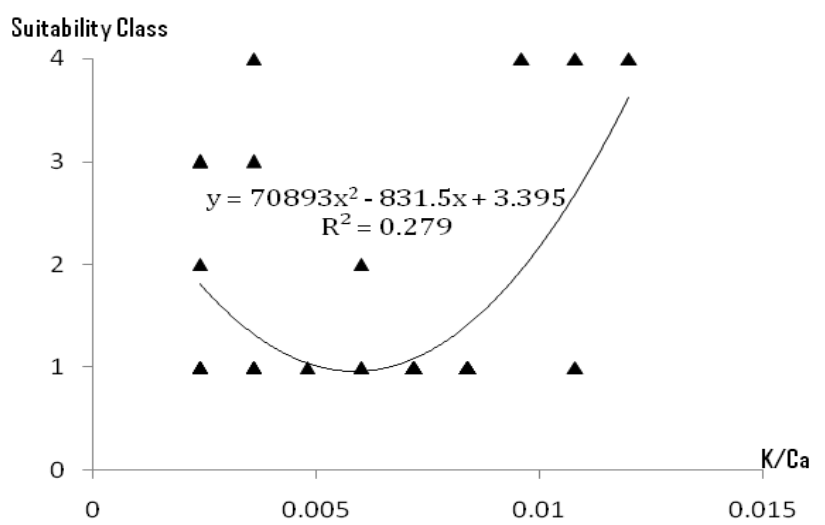

Figure 5. Regression of K/Ca vs suitability class

The results of regression analysis on the relationship between organic matter and land suitability class for sandalwood showed very weak correlation $\left(\mathrm{R}^{2}=0.103\right)$ (Figure 6). This result suggested that the level of organic matter in the soil of Sumba Island was insignificant in the determination of land suitability class for sandalwood perhaps because the distribution of organic matter in soil of Sumba Island had relatively low or similar variation throughout the island.

\section{Multivariate analysis}

Simultaneous analysis was needed to determine the real situation of influence by the indicators, because the indicators could not stand alone in affecting the plant. For example, even though available- $\mathrm{N}$ is abundant, however, the plant growth still could be stunned when the available$\mathrm{P}$ is low. Another example, even $\mathrm{N}$ abundantly available to support photosynthesis process, the absence of Mg could limit the photosynthetic rate. Since the dependent variable in this model is not in metric, we could not conduct multiple regression for analysis. So, we used discriminant analysis to determine the function.

In the first stage, an analysis was carried out to determine which independent variables are suitable for use in the equation. Discriminant analysis is a statistical analysis that was used to determine whether the group differences in the dependent variable are real, and if these differences are real, then it will be further known through the analysis of which independent variables are influential and most influential. In the end, it will be obtained a model or statistical function that is feasible to use.

The result of the statistical analysis using discriminant analysis is to be presented in Table 1. Based on this table, it can be explained using Wilk's Lambda value and its significance value. Wilk's Lambda numbers range from 0 to 1 . If the numbers are close to 0 , it means that the data for each group tends to be different, if the numbers are close to 1 , then the data for each group is the same. From Table 1, Wilk's Lambda value which approaches 0 is only on $\mathrm{P}_{2} \mathrm{O}_{5}$ variable which is 0.244 .

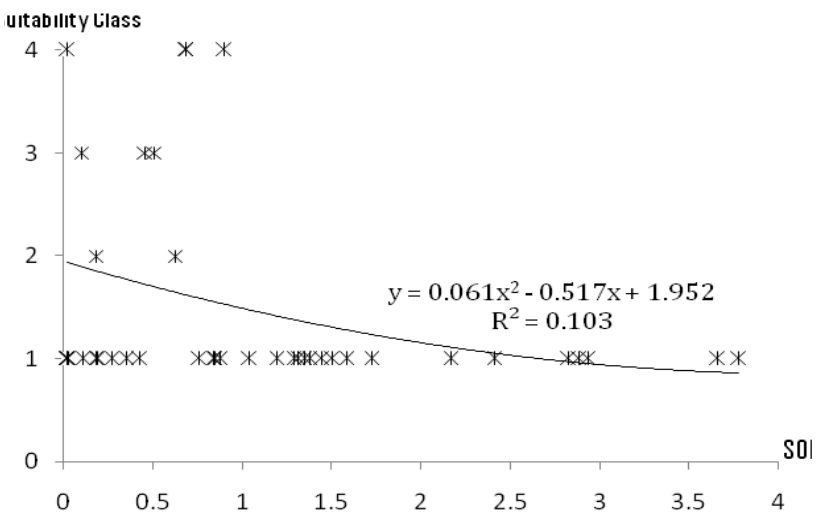

Figure 6. Regression of SOM and suitability class

The next smallest Wilk's Lambda value is the $\mathrm{K} / \mathrm{Ca}$ variable of 0.760 . Variables that have large Wilk's Lambda values are not automatically excluded from the analysis. There are other values that can be used to see whether there are or not differences in groups. $F$ test value or significance, explains that there are differences between groups by a variable if the significance value $<0.05$. Conversely, there is no difference between groups if the significance value $>0.05$. Thus, it can be seen that the variables $\mathrm{P}_{2} \mathrm{O}_{5}$ and $\mathrm{K} / \mathrm{Ca}$ give differences to the suitability class based on the Test $\mathrm{F}$ criteria.

In the second stage, an F test is performed again on the selected variables to ensure that the two variables tend to have different means in each group of suitability classes (Table 2). The $\mathrm{F}$ test results show that the significance value of both is $<0.05$, which means that the variables $\mathrm{P}_{2} \mathrm{O}_{5}$ and $\mathrm{K} / \mathrm{Ca}$ have differences in each group.

Table 1. Tests of equality of group means

\begin{tabular}{lccccc}
\hline & Wilks' Lambda & F & df1 & df2 & Sig. \\
\hline $\mathrm{N}$ & 0.902 & 1.273 & 3 & 35 & 0.299 \\
$\mathrm{P}_{2} \mathrm{O}_{5}$ & 0.244 & 36.130 & 3 & 35 & 0.000 \\
$\mathrm{~K} / \mathrm{Ca}$ & 0.760 & 3.683 & 3 & 35 & 0.021 \\
$\mathrm{SOM}$ & 0.872 & 1.714 & 3 & 35 & 0.182 \\
\hline
\end{tabular}

Table 2. Tests of equality of $\mathrm{P}_{2} \mathrm{O}_{5}$ and $\mathrm{K} / \mathrm{Ca}$ group means

\begin{tabular}{lccccc}
\hline & Wilks' Lambda & F & df1 & df2 & Sig. \\
\hline $\mathrm{P}_{2} \mathrm{O}_{5}$ & 0.244 & 36.130 & 3 & 35 & 0.000 \\
$\mathrm{~K} / \mathrm{Ca}$ & 0.760 & 3.683 & 3 & 35 & 0.021 \\
\hline
\end{tabular}

Table 3. Test results of homogeneity

\begin{tabular}{cll}
\hline Box's M & & $\mathbf{1 6 . 1 8 4}$ \\
\hline & Approx. & 1.822 \\
F & df1 & 6 \\
& df2 & 277.619 \\
& Sig. & 0.095 \\
\hline
\end{tabular}


Table 4. Eigenvalues

\begin{tabular}{lcccc}
\hline Function & $\begin{array}{c}\text { Eigen- } \\
\text { value }\end{array}$ & $\begin{array}{c}\% \text { of } \\
\text { variance }\end{array}$ & $\begin{array}{c}\text { Cumulative } \\
\%\end{array}$ & $\begin{array}{c}\text { Canonical } \\
\text { correlation }\end{array}$ \\
\hline 1 & $3.327^{\mathrm{a}}$ & 91.5 & 91.5 & 0.877 \\
2 & $0.308^{\mathrm{a}}$ & 8.5 & 100.0 & 0.485 \\
\hline
\end{tabular}

Note: a. First 2 canonical discriminant functions were used in the analysis

Table 5. Structure matrix of correlation value

\begin{tabular}{lcc}
\hline & \multicolumn{2}{c}{ Function } \\
\cline { 2 - 3 } & $\mathbf{1}$ & $\mathbf{2}$ \\
\hline $\mathrm{P}_{2} \mathrm{O}_{5}$ & $0.961^{*}$ & 0.276 \\
$\mathrm{~K} / \mathrm{Ca}$ & -0.051 & $0.999^{*}$ \\
\hline
\end{tabular}

Table 6. Canonical discriminant function coefficients

\begin{tabular}{lcc}
\hline & \multicolumn{2}{c}{ Function } \\
\cline { 2 - 3 } & $\mathbf{1}$ & $\mathbf{2}$ \\
\hline $\mathrm{P}_{2} \mathrm{O}_{5}$ & 0.211 & 0.011 \\
$\mathrm{~K} / \mathrm{Ca}$ & -110.098 & 383.259 \\
(Constant) & -3.805 & -2.528 \\
\hline
\end{tabular}

Box's M (Table 3) shows the test results related to variants of the tested variables. The table shows whether the variants in each group are the same or different based on their significance. The variant values for each group should be the same. Based on the test results in the Box's $\mathrm{M}$, the significance level is $>0.05$. So it could be concluded that the value of variance between groups was the same. Thus the analysis could be continued.

Function 1 could be selected based on the canonical correlation value as it shows in Table 4. The canonical correlation number measures the closeness of the relationship between discriminant scores and groups (suitability class). The number 0.887 shows a high correlation, with an association scale ranging from 0 to 1 . The above structure matrix table shows the correlation value between the independent variables and the formed discriminant function (Table 5). The $\mathrm{P}_{2} \mathrm{O}_{5}$ variable has the closest relationship with the discriminant function with a correlation value was 0.961 .

The coefficient value of the discriminant function was shown in Table 6 . The coefficients in the above table have functions similar to multiple regression equations, which in discriminant analysis are called Discriminant functions. Based on the above table (4,5 and 6), the discriminant function could be arranged as follows:

$$
\text { zScore }=-3.805+0.211\left(\mathrm{P}_{2} \mathrm{O}_{5}\right)-110.098(\mathrm{~K} / \mathrm{Ca})
$$

In conclusion, the main limiting or constraint factor in determining the land suitability class for S. album in Sumba Island was the soil phosphorus content that in this study was represented by $\mathrm{P}_{2} \mathrm{O}_{5}$ as its measure. Regression analysis showed a very strong relationship between $\mathrm{P}_{2} \mathrm{O}_{5}$ value with land suitability class for sandalwood with $\mathrm{R}^{2}=$ 0,916 . The equation for that relation was: $y=0.006 \mathrm{x}^{2}-$
$0.323 \mathrm{x}+4.876$. But if it used discriminant analysis as multivariate statistical analysis, the equation form is as follows: $z$ Score $=-3.805+0.211\left(\mathrm{P}_{2} \mathrm{O}_{5}\right)-110.098(\mathrm{~K} / \mathrm{Ca})$. Both in single or multivariate analysis, $\mathrm{P}_{2} \mathrm{O}_{5}$ has the strongest relationship to the land suitability class. Element $P$ should be put as main consideration in the cultivation of sandalwood in Sumba Island. Since the available-P in Sumba Island is a limiting factor, thus the planting of Sandalwood on the island of Sumba must pay attention to the $\mathrm{P}$ content available in the soil and to provide the needed of available-P for the better growth of sandalwood.

\section{REFERENCES}

Abdi H. 2010. Coefficient of Variation. In: Neil S (ed.). Encyclopedia of Research Design. Sage, Thousand Oaks, CA

Abid M, Tian Z, Ata-Ul-Karim ST, Cui Y, Liu Y, Zahoor R, Jiang D, Dai T. 2016. Nitrogen nutrition improves the potential of wheat (Triticum aestivum L.) to alleviate the effects of drought stress during vegetative growth periods. Front Plant Sci 7: 981.

Akpoti K, Kabo-bah AT, Zwart SJ. 2019. Agricultural land suitability analysis: State-of-the-art and outlooks for integration of climate change analysis. Agric Syst 173: 172-208.

Barrett DR, Fox JED. 1997. Santalum album: Kernel composition, morphological and nutrient characteristics of pre-parasitic seedlings under various nutrient regimes. Ann Bot 79: 59-66.

Brand JE, Crombie DS, Mitchell MD. 2013. Establishment and growth of sandalwood (Santalum spicatum) in south-western Australia: The influence of host species. Aust For 63 (1): 60-65.

Brand JE, Robinson N, Archibald RD. 2003. Establishment and growth of sandalwood (Santalum spicatum) in south-western Australia: Acacia host trials. Austr For 66 (4): 294-299.

Burdock GA, Carabin IG, 2008. Safety assessment of sandalwood oil (Santalum album L.). Food Chem Toxicol 46 (2): 421-432.

Crous KY, Osvaldsson A, Ellsworth DS. 2015. Is phosphorus limiting in a mature Eucalyptus woodland? Phosphorus fertilisation stimulates stem growth. Plant Soil 391 (1-2): 293-305.

Das SC, Das S, Tah J. 2018. Effect of soil nutrients on the growth and survivability of white sandal (Santalum album L) in South West Bengal. Intl J Cur Res 10 (12): 76264-76267.

Deepa P, Yusuf A. 2016. Influence of different host associations on glutamine synthetase activity and ammonium transporter in Santalum album L. Physiol Mol Biol Plants 22 (3): 331-340. DOI: 10.1007/s12298-016-0368-9

Diedhiou I, et al. 2017. Allometric equations and carbon stocks in tree biomass of Jatropha curcas L . in Senegal's Peanut Basin. Glob Ecol Conserv 9: 61-69.

Gediya SK, Mistry RB, Patel UK, Blessy M, Jain HN. 2011. Herbal plants: used as cosmetics. J Nat Prod Plant Resour 1 (1): 24-32.

Gomes D, Adnyana. 2017. The effect of legume and non-legume to the sandalwood (Santalum album Linn.) growth in Timor Leste. Intl J Sci Basic Appl Res 32 (1): 207-237.

Hendrik AC, Kusmana C, Muhdin. 2019. Stand and site characteristics of kabesak (Acacia leucophloea) in Timor Island, East Nusa Tenggara, Indonesia. JPK Wallacea 8 (2): 147-157.

Hettiarachchi D, Liu Y, Fox J, Sunderland B. 2010. Western Australian sandalwood seed oil: new opportunities. Lipid Technol 22 (2): 27-29.

IUCN [International Union for Conservation of Nature and Natural Resources]. 2015. Santalum album. DOI: 10.2305/IUCN.UK. 1998.RLTS.T31852A9665066.en

James EK. 2017. Nitrogen Fixation. In: Brian T, Brian GM, Denis JM (eds) Encyclopedia of Applied Plant Sciences, Vol 1. Academic Press, Waltham, MA.

Jara MC, et al. 2015. Guidelines for documenting and reporting tree allometric equations. Ann For Sci 72: 763-768.

Kozak M, Bocianowski J, Rybinski W. 2013. Note on the use of coefficient of variation for data from agricultural factorial experiments. Bulg J Agric Sci 19 (4): 644-646

Kurniawan H, Sumardi. 2013. Seminar regional. In: Raharjo S et al. (eds) Prosiding Seminar Regional Pembangunan Kehutanan Berkelanjutan dalam Perspektif Tata Ruang. Balai Penelitian Kehutanan Kupang- 
Badan Penelitian, Pengembangan dan Inovasi, Kementerian LHK, Kupang. [Indonesian]

Liu XJ, Xu DP, Xie ZS, Zhang NN. 2009. Effects of different culture media on the growth of Indian sandalwood (Santalum album L.) seedlings in Zhanjiang, Guangdong, southern China. For Stud China 11 (2): 132-138. DOI: 10.1007/s11632-009-0023-4

Liyanda MKA, Abubakar Y. 2012. Analisis kriteria kesesuaian lahan terhadap produksi kakao pada tiga klaster pengembangan di Kabupaten Pidie (Analysis of land suitability criteria for cocoa production of three cluster development in Pidie District). Agrista 16 (2): 62-79. [Indonesian]

$\mathrm{Lu} \mathrm{K.} \mathrm{2014.} \mathrm{Host-species-dependent} \mathrm{physiological} \mathrm{characteristics} \mathrm{of}$ hemiparasite Santalum album in association with $\mathrm{N}_{2}$-fixing and non$\mathrm{N}_{2}$-fixing hosts native to southern China. Tree Physiol 34: 1006-1017.

Lu JK. 2013. Two-way transfer of nitrogen between Dalbergia odorifera and its hemiparasite Santalum album is enhanced when the host is effectively nodulated and fixing nitrogen. Tree Physiol 33: 464-474.

Luo FL, Guo QS. 2010. Influences of host species on transpiration, photosynthesis, chlorophyll and mineral contents of medicinal hemiparasite Thesium chinense Turcz. Acta Physiol Plant 32: 1093 1102.

Mahmud K, Makaju S, Ibrahim R, Missaoui A. 2020. Current Progress in nitrogen fixing plants and microbiome research. Plants 9: 97. DOI: $10.3390 /$ plants 9010097 .

Mascaro J, Litton CM, Hughes RF, Uowolo A, Schnitzer SA. 2011 Minimizing bias in biomass allometry: Model selection and logtransformation of data. Biotropica 43 (6): 649-653.

Mega IM. 2010. Klasifikasi Tanah dan Kesesuaian Lahan. Program Studi Agroekoteknologi, Universitas Udayana, Denpasar. [Indonesian]

Mujahid TY, Subhan SA, Wahab A, Masnoon J, Ahmed N, Abbas T. 2015. Effects of different physical and chemical parameters on phosphate solubilization activity of plant growth-promoting bacteria isolated from indigenous soil. J Pharm Nutr Sci 5 (1): 64-70.

Moyin-Jesu EI. 2015. Use of different organic fertilizers on soil fertility improvement, growth and head yield parameters of cabbage (Brassica oleracea L). Intl J Recycl Org Waste Agric 4 (4): 291-298.

Nahrawi H, Husni MHA, Othman R, Bah A. 2011. Decomposition of leaf and fine root residues of three different crop species in tropical peat under controlled conditions. Malays J Soil Sci 15: 63-74.

Njurumana GND, Hidayatullah M, Butarbutar T. 2008. Kondisi tanah pada sistem kaliwu dan mamar di Timor dan Sumba (Condition of soil at Mamar and Kaliwu system in Timor and Sumba). Info Hutan 5 (1): 45-51. [Indonesian]

Nur MSM. 2014. Orasi ilmiah: Aplikasi POSCHAR Suatu Teknologi untuk Meningkatkan Ketersediaan Fosfor, Kesuburan dan Produktivitas Calcarosol di Timor Barat. Universitas Nusa Cendana, Kupang. [Indonesian]

Ouyang Y, Zhang X, Chen Y, da Silva JAT, Ma G. 2016. Growth, photosynthesis and haustorial development of semiparasitic Santalum album L. penetrating into roots of three hosts: a comparative study. Trees 30: 317-328. DOI: 10.1007/s00468-015-1303-3.

Peden C. 2017. Tropical Forestry Services: A Case Study of Embracing Entrepreneurial Leadership in Charting East-West Markets for Ancient Indian Sandalwood. In: Muenjohn N, McMurray A (eds) Palgrave Handbook of Leadership in Transforming Asia, Springer, Nederlands. http://link.springer.com/10.1057/978-1-137-57940-9.
Prado RM. 2010. Phosphorus effects in the nutrition and growth of developing mango plants. J Plant Nutr 33 (14): 2041-2049.

Radomiljac AM, McComb JA, McGrath JF. 1999. Intermediate host influences on the root hemi-parasite Santalum album L. biomass partitioning. For Ecol Manag 113 (2-3): 143-153.

Radomiljac AM, McComb JA, Shea SR. 1998. Field establishment of Santalum album L.-The effect of the time of introduction of a pot host (Alternanthera nana R. Br.). For Ecol Manag 111: 107-118.

Ratnaningrum YWN, Faridah E, Indrioko S, Syahbudin A. 2016. Flowering and seed production of sandalwood (Santalum album; Santalaceae) along environmental gradients in Gunung Sewu Geopark, Indonesia. Nusantara Biosci 8 (2): 180-191. DOI: 10.13057/nusbiosci/n080209.

Rocha D 2014. Influence of host plant on the physiological attributes of field-grown sandal tree (Santalum album ). J Trop For Sci 26 (2): 166-172.

Rohadi D, Setyawati T, Maryani R, Riwukaho M, Gilmour D, Boroh P, Septiani Y, Lukas E. 2012. Strategies for sustaining sandalwood resources in East Nusa Tenggara, Indonesia. Asia and The Pacific Workshop, Multinational and Transboundary Conservation of Valuable and Endangered Forest Tree Species. IUFRO World Series 30: 69-71.

Rorie RL, Purcell LC, Karcher DE, King CA. 2011. The assessment of leaf nitrogen in corn from digital images. Crop Sci 51 (5): 2174-2180. DOI: $10.2135 /$ cropsci2010.12.0699

Sarwar G, Schmeisky H, Hussain N, Muhammad S, Ibrahim M, Safdar E. 2008. Improvement of soil physical and chemical properties with compost application in rice-wheat cropping system. Pak J Bot 40 (1): 275-282.

Septiani Y, Setyawati T. 2012. Sandalwood resources and its management in east Nusa Tenggara Timor Province, Indonesia. Proceedings of International Sandalwood Symposium 21-24.

Seran YN, Sudarto S, Hakim L, Arisoesilaningsih E. 2018. Sandalwood (Santalum album) growth and farming success strengthen its natural conservation in Timor Island, Indonesia. Biodiversitas 19 (4): 15861592.

Struthers R. 1986. Mineral nutrition of sandalwood (Santalum spicatum). J Exp Bot 37: 1274-1284.

Taylor P. 2005. Refinement of potting medium ingredients for production of high-quality seedlings of sandalwood (Santalum album L.). Austr For 68 (1): 44-49.

Teixeira da Silva JA, Kher MM, Soner D, Page T, Zhang X, Nataraj M, Ma G. 2016. Sandalwood: basic biology, tissue culture, and genetic transformation. Planta 243: 847-887. DOI: 10.1007/s00425-0152452-8.

Verma RK, Thakur AK, Rajput PS. 2012. Effect of organic amendments and plant growth-promoting microbes on Santalum album in Central India. Indian For 138 (8): 742-746.

Weil RR, Brady NC. 2017. Phosphorous and Potassium. Chapter 14. The Nature and Properties of Soils, $15^{\text {th }}$ ed. Pearson, Columbus, OH, USA.

Yu W, Ding X, Xue S, Li S, Liao X, Wang R. 2013. Effects of organic matter application on phosphorus adsorption in three soil parent materials. J Soil Sci Plant Nutr 13: 1003-1017. 